\title{
YIELD AND PROXIMATE COMPOSITION OF SEA-TROUT FROM SOUTHERN BRAZIL*
}

\author{
by \\ Ko WatANABE** \\ (Received Mar. 19, 1963)
}

\begin{abstract}
Introduction
In a previous paper ${ }^{1)}$ the proximate composition of four species of commercially important fishes from southern Brazil were outlined in a general manner. The purpose of this work is to examine more closely the variation extent for various factors in the sea-trout, "pescadafoguete" Macrodon ancylodon, which contributes about quarter of the landings by weight at Santos ${ }^{213}$. The proximate composition is analyzed chemically and physically and the results are subjected to the analysis of variance using data obtained in 1961.
\end{abstract}

\section{Material and Methods}

Samples were taken from two areas, off Santos (Lat. $24^{\circ} \mathrm{S}-15^{\circ} \mathrm{S}$ ), and off the coast of the state of Rio Grande do Sul (Lat. $29^{\circ} \mathrm{S}-33^{\circ} \mathrm{S}$ ), using only for this purpose fish from vessels which would and could supply accurate information as to the locale of their fishing. All samples were taken at the Santos Fish Pier, those from the local vessels on the same day as they were captured, those from the distant-water vessels chosen from lots of apparent good quality which had been stored in ice for a maximum of six days.

Samples were taken in February-March, May-June, August-September, and November-December, collecting for a few inconsecutive days each period until a total of 30-50 fishes was obtained, 3-5 individuals from Santos and 10-15 individuals from Rio Grande do Sul each day.

Body lengths were recorded to the nearest half-centimeter following the method described by Nomura"), and stages of maturity were determined in a seven point scale as described by $\mathrm{VAzZOLER}^{5}$. Weights were determined to the nearest gram for the whole fish and for its components, such as fillet, viscera, head, skin, scale and residues which indicate the total weight of the beheaded skelton after filleting, including tail, vertical and dorsal fins, and adhering meat. The term loss is used to indicate the total weight of each fish minus the determined sum of the weight of all component of the part of that fish.

Samples were prepared in the laboratory always on the same day in which they

* Contribution No. 181 from Instituto Oceanográfico, Universidade de São Paulo, Brazil.

** Instituto Oceanogräfico (渡辺惓, サンパウロ大学海洋学研究所). 
Table 1. Yield of sea-trout from southern Brazil, shown in average percentage of total weight, by areas and seasons.

\begin{tabular}{|c|c|c|c|c|c|c|c|c|c|c|c|c|c|}
\hline \multirow{2}{*}{ Area } & \multirow{2}{*}{$\begin{array}{l}\text { No. of } \\
\text { fish }\end{array}$} & \multirow{2}{*}{ Month } & \multirow{2}{*}{ Item } & \multicolumn{2}{|c|}{ Body } & \multirow{2}{*}{$\begin{array}{l}\text { Fillet } \\
(\%)\end{array}$} & \multirow{2}{*}{\multicolumn{2}{|c|}{$\begin{array}{c}\text { Viscera (gonad) } \\
(\%)\end{array}$}} & \multirow{2}{*}{$\begin{array}{l}\text { Head } \\
(\%)\end{array}$} & \multirow{2}{*}{$\begin{array}{r}\text { Skin } \\
(\%)\end{array}$} & \multirow{2}{*}{$\begin{array}{l}\text { Scale } \\
(\%)\end{array}$} & \multirow{2}{*}{$\begin{array}{c}\text { Residue } \\
(\%)\end{array}$} & \multirow{2}{*}{$\begin{array}{l}\text { Loss } \\
\qquad(\%)\end{array}$} \\
\hline & & & & $\begin{array}{c}\text { weight } \\
\text { (gr.) }\end{array}$ & $\begin{array}{c}\text { length } \\
\text { (cm.) }\end{array}$ & & & & & & & & \\
\hline \multirow{7}{*}{ Santos } & 32 & $\begin{array}{l}\text { Feb. } \\
\text { March }\end{array}$ & $\begin{array}{l}\text { mean } \\
\text { range }\end{array}$ & $\begin{array}{c}30.5 \\
23.0-40.5\end{array}$ & $\begin{array}{l}266.2 \\
89-588\end{array}$ & $\begin{array}{c}45.3 \\
40.3-50.0\end{array}$ & $\begin{array}{c}6.9 \\
3.1-15.6\end{array}$ & $\begin{array}{c}(0.8) \\
(0.1-6.0)\end{array}$ & $\begin{array}{c}14.9 \\
11.2-18.8\end{array}$ & $\begin{array}{c}15.0 \\
10.7-20.6\end{array}$ & $\begin{array}{c}0.5 \\
0.1-1.0\end{array}$ & $\begin{array}{c}16.4 \\
12.3-22.6\end{array}$ & $\begin{array}{c}1.0 \\
0.2-5.0\end{array}$ \\
\hline & 51 & May & mean & 29.7 & 245.4 & 45.2 & 7.0 & (1.3) & 18.6 & 13.3 & 0.5 & 14.7 & 0.8 \\
\hline & & June & range & $22.5-37.0$ & $56-563$ & $34.5-54.8$ & $2.5-15.9$ & $(0.1-9.6)$ & $11.4-22.5$ & $8.4-22.5$ & $0.2-1.8$ & $8.8-17.5$ & $0.0-7.4$ \\
\hline & 36 & Aug. & mean & 29.6 & 237.8 & 45.4 & 5.9 & $(0.9)$ & 20.7 & 13.4 & 0.7 & 11.5 & 2.4 \\
\hline & & Sept. & range & $23.0-38.0$ & $88-462$ & $36.4-53.1$ & $2.9-10.7$ & $(0.2-7.1)$ & $17.2-25.8$ & $9.1-25.0$ & $0.2-1.8$ & $9.6-17.0$ & $0.2-7.2$ \\
\hline & 32 & Nov. & mean & 31.6 & 264.8 & 44.4 & 5.7 & $(0.5)$ & 21.4 & 15.6 & 0.6 & 10.6 & 1.6 \\
\hline & & Dec. & range & $22.5-37.5$ & $77-410$ & $39.2-51.0$ & $2.5-10.3$ & $(0.2-1.0)$ & $16.6-26.0$ & $8.4-22.5$ & $0.1-1.4$ & $8.2-16.8$ & $0.5-5.1$ \\
\hline \multirow{8}{*}{$\begin{array}{c}\text { Rio } \\
\text { Grande } \\
\text { do Sul }\end{array}$} & 45 & Feb. & mean & 30.1 & 238.8 & 43.7 & 11.7 & $(2: 7)$ & 14.7 & 14.0 & 0.7 & 16.3 & 1.2 \\
\hline & & March & range & $23.0-36.0$ & $94-400$ & $37.2-51.8$ & $5.8-20.2$ & $(0.5-8.0$ & $12.3-16.9$ & $8.4-17.8$ & $0.2-1.3$ & $11.6-20.1$ & $0.0-3.5$ \\
\hline & 5 & May & mean & 30.7 & 303.8 & 45.9 & 8.0 & $(0.6)$ & 17.0 & 14.5 & 0.7 & 13.1 & 0.9 \\
\hline & & June & range & $21.0-44.0$ & $69-752$ & $38.1-52.5$ & $3.8-13.4$ & $(0.2-1.2)$ & $13.5-20.1$ & $9.1-23.1$ & $0.2-1.7$ & $7.6-16.0$ & $0.6-5.3$ \\
\hline & 48 & Aug. & mean & 30.9 & 379.3 & 48.2 & 6.7 & (1.1) & 17.9 & 14.5 & 0.7 & 10.6 & 1.3 \\
\hline & & Sept. & range & $24.5-44$ & $115-945$ & $39.0-52.0$ & $2.4-14.2$ & $(0.1-4.9)$ & $13.9-21.0$ & $8.5-23.4$ & $0.3-1.1$ & $7.2-14.0$ & $0.5-6.0$ \\
\hline & 40 & Nov. & mean & 31.8 & 319.9 & 44.3 & 11.8 & (3.9) & 15.8 & 13.5 & 0.6 & 13.2 & 0.8 \\
\hline & & Dec. & range & $24.5-41$ & $123-613$ & $37.4-48.8$ & $6.2-16.9$ & $(0.5-12.3)$ & $13.5-18.6$ & $9.0-17.8$ & $0.2-1.1$ & $11.1-15.6$ & $0.0-6.9$ \\
\hline
\end{tabular}


Table 2. Chemical composition of sea-trout, shown in average percentage by sex, size, stage of maturity and season.

\begin{tabular}{|c|c|c|c|c|c|c|c|c|c|c|c|c|c|c|c|}
\hline \multirow{4}{*}{$\begin{array}{c}\text { Factors } \\
\text { Sex }\end{array}$} & \multirow{4}{*}{$\begin{array}{c}\text { Item } \\
\text { male } \\
\text { female }\end{array}$} & \multicolumn{6}{|c|}{ Santos } & \multicolumn{8}{|c|}{ Rio Grande do Sul } \\
\hline & & \multicolumn{2}{|c|}{$\begin{array}{l}\text { Moisture } \\
\text { Mean S.D.* } \\
(\%)\end{array}$} & $\begin{array}{c}\text { Oil } \\
\text { Mean S.D. } \\
(\%)\end{array}$ & $\begin{array}{c}\text { Ash } \\
\text { Mean S.D. } \\
(\%)\end{array}$ & \multicolumn{2}{|c|}{$\begin{array}{l}\text { Protein } \\
\text { Mean S.D. } \\
(\%)\end{array}$} & \multicolumn{2}{|c|}{$\begin{array}{c}\text { Moisture } \\
\text { Mean S.D. } \\
(\%)\end{array}$} & \multicolumn{2}{|c|}{$\begin{array}{c}\text { Oil } \\
\text { Mean S.D. } \\
(\%)\end{array}$} & \multicolumn{2}{|c|}{$\begin{array}{c}\text { Ash } \\
\text { Mean S.D. } \\
(\%)\end{array}$} & \multicolumn{2}{|c|}{$\begin{array}{c}\text { Protein } \\
\text { Mean S.D. } \\
(\%)\end{array}$} \\
\hline & & 77.8 & 2.6 & $\begin{array}{ll}2.8 & 1.9\end{array}$ & $\begin{array}{ll}2.3 & 0.8\end{array}$ & 18.7 & 1.1 & 77.4 & 3.0 & 4.6 & 2.2 & 1.9 & 0.6 & 17.1 & 2.8 \\
\hline & & 76.7 & 3.3 & $\begin{array}{ll}3.9 & 2.7\end{array}$ & $2.4 \quad 0.6$ & 17.9 & 1.5 & 76.7 & 2.1 & 5.5 & 2.4 & 1.9 & 0.8 & 17.3 & 1.2 \\
\hline \multirow{2}{*}{$\begin{array}{l}\text { Body } \\
\text { length }\end{array}$} & $>30 \mathrm{~cm}$ & 76.9 & 2.8 & $5.2 \quad 3.2$ & $2.1 \quad 0.6$ & 18.5 & 1.4 & 75.9 & 2.4 & 5.4 & 2.4 & 1.9 & 0.5 & 17.4 & 1.5 \\
\hline & $\leqq 30 \mathrm{~cm}$ & 76.6 & 2.3 & $\begin{array}{ll}1.6 & 1.1\end{array}$ & $2.2 \quad 0.7$ & 17.6 & 1.4 & 78.4 & 2.6 & 4.8 & 2.3 & 1.9 & 0.5 & 17.0 & 0.5 \\
\hline \multirow{2}{*}{$\begin{array}{l}\text { Stage of } \\
\text { maturity** }\end{array}$} & I, II, III. & 77.1 & 3.1 & $2.9 \quad 2.2$ & $2.2 \quad 0.6$ & 18.9 & 1.3 & 75.7 & 2.4 & 6.6 & 2.0 & 1.8 & 0.3 & 17.1 & 1.0 \\
\hline & IV, V, VI. & 75.3 & 2.7 & $5.1 \quad 2.3$ & 2.10 .8 & 17.7 & 1.2 & 77.9 & 2.1 & 4.0 & 2.0 & 2.0 & 0.6 & 17.3 & 1.3 \\
\hline \multirow{4}{*}{ Season } & Feb., March & 75.6 & 2.9 & $3.4 \quad 2.5$ & $2.4 \quad 0.6$ & 17.8 & 1.6 & 78.7 & 1.7 & 2.3 & 1.3 & 2.4 & 0.5 & 17.2 & 1.4 \\
\hline & May, June & 77.4 & 3.1 & $\begin{array}{ll}3.9 & 2.5\end{array}$ & $2.1 \quad 0.6$ & 18.1 & 1.3 & 75.6 & 2.5 & 6.1 & 6.0 & 2.1 & 0.4 & 16.8 & 1.1 \\
\hline & Aug., Sept. & 75.0 & 3.1 & $3.4 \quad 2.5$ & $\begin{array}{ll}2.2 & 0.8\end{array}$ & 18.2 & 1.1 & 75.8 & 2.3 & 6.8 & 2.0 & 1.6 & 0.3 & 17.6 & 0.9 \\
\hline & Nov,, Dec. & 78.1 & 3.0 & $2.8 \quad 2.4$ & $2.0 \quad 0.4$ & 18.3 & 1.0 & 78.2 & 1.5 & 4.7 & 1.4 & 1.6 & 0.5 & 17.5 & 1.2 \\
\hline
\end{tabular}

* Standard deviation.

** I, II, III. Immature to maturing.

IV., V., VI. Mature to spawning. 
were collected by first grinding and then homogenizing in a blendor, after which the chemical determinations were made by the same methods outlined previously ${ }^{1}$.

\section{Results}

1) Yield.

Table 1 shows the percentages by weight of the component parts of the fish. The yield of fillet from the Santos fish was rather uniform throughout the year, about $45 \%$, while the Rio Grande do Sul fish were slightly more variable, $44-48 \%$.

Table 3. $F$ values of the analysis of variance applied on the results of Table 2, of significance of the differences between sexes, sizes, stages of maturity and seasons for each component, with areas separately.

\begin{tabular}{|c|c|c|c|c|c|c|c|c|c|c|}
\hline \multirow[b]{2}{*}{ Factors } & \multicolumn{5}{|c|}{ Santos } & \multicolumn{5}{|c|}{ Rio Grande do Sul } \\
\hline & $\begin{array}{c}\text { Degree } \\
\text { of } \\
\text { freedom }\end{array}$ & Moisture & Oil & Ash & Protein & $\begin{array}{l}\text { Degree } \\
\text { of } \\
\text { freedom }\end{array}$ & Moisture & Oil & Ash & Protein \\
\hline Sex & $\begin{array}{l}n_{1}=1 \\
n_{2}=141\end{array}$ & $12.24 *$ & $7.70 *$ & 2.72 & 1.21 & $\begin{array}{l}n_{1}=1 \\
n_{2}=172\end{array}$ & $16.49 *$ & $5.06 * *$ & 0.24 & $3.94 * *$ \\
\hline $\begin{array}{c}\text { Body } \\
\text { length }\end{array}$ & $\begin{array}{l}\mathbf{n}_{1}=1 \\
\mathbf{n}_{2}=143\end{array}$ & $77.40 *$ & $12.77 *$ & $5.35^{* *}$ & 0.08 & $\begin{array}{l}\mathbf{n}_{1}=1 \\
\mathbf{n}_{\mathbf{2}}=172\end{array}$ & $15.55 *$ & 1.10 & 0.03 & $5.00 * *$ \\
\hline $\begin{array}{l}\text { Stage of } \\
\text { maturity }\end{array}$ & $\begin{array}{l}\mathrm{n}_{1}=1 \\
\mathrm{n}_{2}=143\end{array}$ & $17.38^{*}$ & $39.09 *$ & 0.11 & 0.40 & $\begin{array}{l}n_{1}=1 \\
n_{2}=172\end{array}$ & $54.35^{*}$ & $66.28 *$ & 3.26 & 1.32 \\
\hline Season & $\begin{array}{l}\mathrm{n}_{1}=3 \\
\mathrm{n}_{2}=141\end{array}$ & $4.82^{*}$ & 1.09 & $2.78^{* *}$ & $3.01 * *$ & $\begin{array}{l}\mathrm{n}_{1}=3 \\
\mathrm{n}_{2}=170\end{array}$ & 2.09 & $55.88^{*}$ & $38.12^{*}$ & $4.47^{*}$ \\
\hline
\end{tabular}

* Significant at the $1 \%$ confidence level.

** Significant at the $5 \%$ confidence level.

Table 4. $F$ values of the analysis of variance applied on the results of Table 2, of significance of the difference between areas, for seasons and components.

\begin{tabular}{l|l|l|l|l|l}
\hline Month & $\begin{array}{l}\text { Degree } \\
\text { of } \\
\text { freedom }\end{array}$ & Moisture & Oil & Ash & Protein \\
\hline $\begin{array}{l}\text { Feb. } \\
\text { March }\end{array}$ & $\begin{array}{l}\mathrm{n}_{1}=1 \\
\mathrm{n}_{2}=71\end{array}$ & $11.42^{*}$ & $5.79^{* *}$ & 0.01 & 3.75 \\
\hline $\begin{array}{l}\text { May } \\
\text { June }\end{array}$ & $\begin{array}{l}\mathrm{n}_{1}=1 \\
\mathrm{n}_{2}=92\end{array}$ & $9.87^{*}$ & $23.20^{*}$ & 0.04 & $26.30^{*}$ \\
\hline $\begin{array}{l}\text { Aug. } \\
\text { Sept. }\end{array}$ & $\begin{array}{l}\mathrm{n}_{1}=1 \\
\mathrm{n}_{2}=82\end{array}$ & $29.71^{*}$ & $44.76^{*}$ & 1.91 & $24.62^{*}$ \\
\hline $\begin{array}{l}\text { Nov. } \\
\text { Dec. }\end{array}$ & $\begin{array}{l}\mathrm{n}_{1}=1 \\
\mathrm{n}_{2}=66\end{array}$ & 0.05 & $16.81^{*}$ & $12.95^{*}$ & $7.31^{*}$ \\
\hline
\end{tabular}

* Significant at the $1 \%$ confidence level.

** Significant at the $5 \%$ confidence level.
This is evidently associated inversely with gonad weight.

2) Chemical composition.

Table 2 demonstrates the annual mean values and the seasonal variations in chemical composition, analyzed for sex, length, and stage of maturity, for the two areas of capture. Tables 3 and 4 are devoted to statistical analysis of Table 2 .

Protein and ash appear to vary only with season, with more significant results from Rio Grande do Sul (1\% level) than from Santos $(5 \%$ level). Ash was higher for Santos 
fish toward the end of the year, and protein slightly higher for these same fish the latter half of the year.

Moisture varied significantly with all factors except season for Rio Grande do Sul at $1 \%$ level, and between the two areas except at the very end of the year.

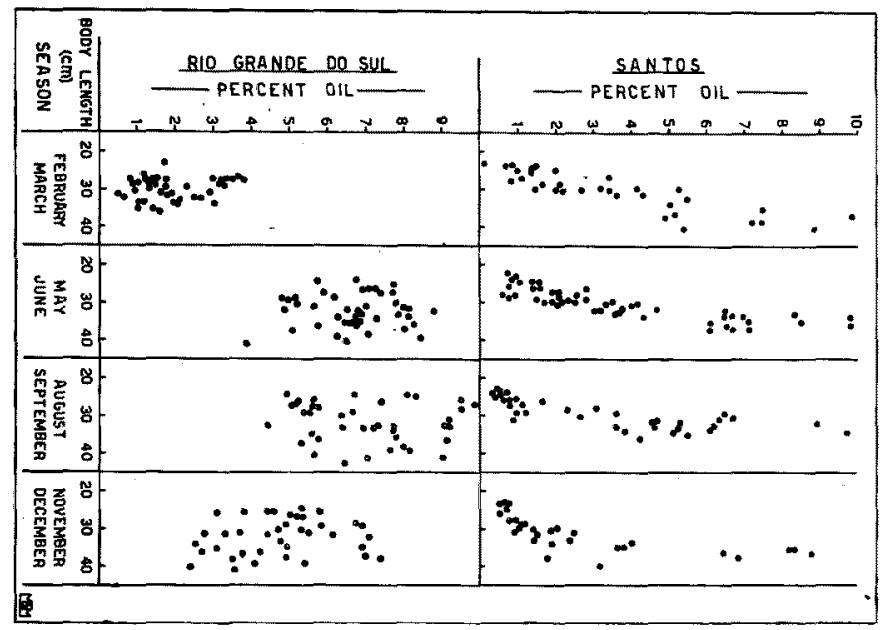

Fig. 1. Variation in oil content of sea-trout by seasons, areas and sizes of fish.

Oil content was much more variable than other parameters examined. Female had consistently more oil than the males by about $1 \%$, with the highest and lowest values obtained on an annual basis ranging from $5.5 \%$ of Rio Grande do Sul female to $2.8 \%$ of Santos male.

Variation of oil content with size was also observed (Fig. 1), with larger fish containing more oil at Santos, which was equal to that of Rio Grande do Sul larger fish; however the smaller fish from the south had up to three times as much oil as the

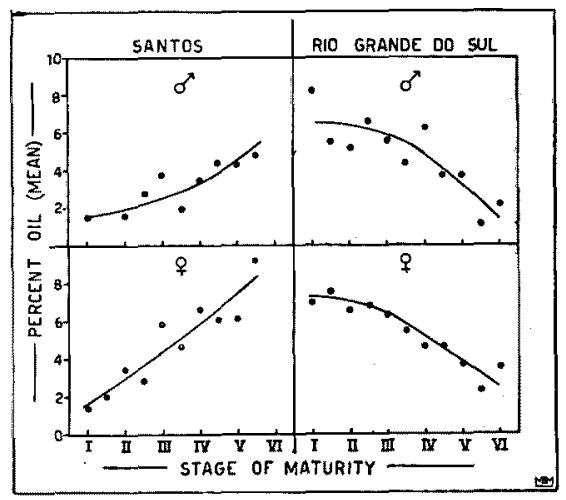

Fig. 2. Relationship between oil con. tent and stage of maturity of seatrout, fitted with free hand curves. Santos smaller fish. In comparing this with previous work $^{1 /}$ on Santos samples it should be considered that in this work the fish were bigger.

Fishes in early stages of ripeness had less oil than those in later stages in Santos; the reverse was true for Rio Grande do Sul (Fig. 2). Another regional difference may be seen in that Santos females increase their oil content more rapidly with ripening than do the males, while a more nearly parallel development is typical of Rio Grande do Sul. 
As might be expected from the studies of ripeness, the Grande do Sul catch oil content varied with time of year, lowest in the early part, around $2 \%$, to $7 \%$ in AugustSeptember. On the other hand the Santos fish did not show this tendency. Overall, the Rio Grande do Sul catch was considerably oilier than the Santos catch.

\section{Discussion}

As may be seen in Table 1, fish from Rio Grande do Sul tend to have roe at the end of the year which may be as large as $12 \%$ of the total weight. This rises the interesting possibility that this considerable percentage of the total weight, now used in fish meal or discarded, might be processed to make an acceptable food product.

The values given for fillet yield here are probably a little low, since the filleting was done in the laboratory and undoubtedly a trained professional would get more meat from each fish. We found efficient production of skinless fillets difficult, due to the weak consistency of the skin, especially when the fish were not quite fresh.

Tanigawa $^{6)}$ pointed out that oil content is closely associated with good taste in fresh and canned fisheries products. Considering this, it may be predicated that taste will vary with oil content, with the best tasting products being the Rio Grande do Sul fish most of the year, and of the Santos fish the larger ones. This is com-

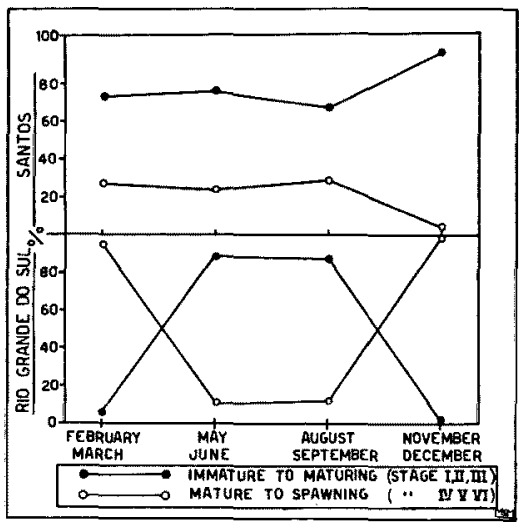

Fig. 3. Seasonal variation of stage of maturity of sea-trout sampled, shown as percentage of immature to maturing and mature to spawing. pensated, however, by the lesser tendency to rancidity in the other fish, which might be more efficiently stored in frozen or salted-dried conditions.

The present results showed that the variation in oil content due to stage of maturity was larger than any of those due to sex, size and season.

The largely differed variations in oil content in the two localities demonstrated here were difficult to be explained by the simple differences in the maturity and spawning patterns (Fig. 3) 7),8). As Love ${ }^{9 !}$ pointed it out, further data on feeding and migratory behavior of the fish in the two areas should be taken into consideration to clarify this matter.

\section{Acknowledgement}

The author is grateful for "Cooperativa Mista de Pesca Nipo-Brasileira" and "Sociedata de pesca Taiyo Ltda" for providing materials gratis. Thanks are also 
due to Misses Dulcinda Rodrigues da Silva and Eunice Maria dos Santos for their technical assistance.

\section{Summary}

Whole body of sea-trout was analysed physically and chemically and the results were subjected to the statistical analysis, in terms of sex, size, stage of maturity, season and area of catch.

Fillet yield was about $45 \%$ of total weight for Santos fish, but varied seasonally ranging from $44 \%$ to $48 \%$ for Rio Grande do Sul.

Oil, moisture, ash and protein contents were determined and discusser on each factor responsible for their variations.

Larger fish contained equal oil in the both areas, but the smaller one from Rio Grande do Sul had three times as much oil as the Santos fish.

Fishes in early stages of ripeness and less oil than those in later stages in Santos and the vice versa in Rio Grande do Sul. Overall, the Rio Grande do Sul catch was considerably oilier than the Santos catch.

\section{References}

1) K. Watanabe: Bul. Jap. Soc. Sci. Fish., Vol. 29, No. 5, 469 (1963).

2) I. D. RICHARDSON \& M. N. Moraes: Bol. Inst. Ocean., 11, no 1, 10 (1960).

3) Grupo de pesquisas sôbre pesca marítima: Tabelas de dados sôbre a pesca marítima, Bazil (1961).

4) H. Nomura: Bol. Inst. Ocean., 11, no 1, 99 (1960).

5) A.E. A. M. VAzzoler et al.: IIla Reunião nacional de técnicos em pesquisas sôbre a pesca marítima, Anexo 8, 10, Florianópolis, Santa Catarina, Brazil (mimeographed), (1962).

6) E. Tanigawa: Manufacture of canned products, Kigen-sha, Tokyo, 360 (1958).

7) F.J.S. LaRA: An. Acad. Bras. Ci., 23, no 3, 291, (1951).

8) N. YAMAGUCHI: in preparation (1963).

9) R. M. Love: The physiology of fishes, Academic Press, New York, 1, 405 (1957). 